\title{
Postpamięć jako marzenie senne - Achtung Zelig! Druga wojna Krzysztofa Gawronkiewicza i Krystiana Rosenberga ${ }_{\left[{ }^{[}\right]}$
}

Termin postpamięć (postmemory) wprowadziła Marianne Hirsch w pracy Family Frames: Photography, Narrative and Postmemory jako kategorię opisu sytuacji psychicznej dzieci ofiar Holocaustu. Badaczka terminem tym zaznaczała cechy doświadczeń osób, które dorastały w cieniu opowieści o zdarzeniach rozgrywających się przed ich urodzeniem. Ich własne wspomnienia musiały ustąpić miejsca historiom dziadków i/lub rodziców, ukształtowanym w traumatycznych okolicznościach [2]. Z tak rozumianą postpamięcią mamy do czynienia np. w dwutomowym komiksie Maus: opowieść ocalałego Arta Spiegelmana, w którym młody mężczyzna przedstawia losy swoich rodziców w okupowanej Polsce, a jednocześnie wskazuje, jak pobyt jego ojca w nazistowskim obozie zagłady Auschwitz zdeterminował charakter więzi emocjonalnych między rodzicem a dzieckiem.

Wkrótce jednak terminem postpamięć zaczęto określać także zjawiska wykraczające poza sytuację psychiczną dzieci ofiar Holocaustu, na przykład pamięć zapożyczoną czy wręcz przywłaszczoną przez ludzi „wspominających” wydarzenia, których nie byli uczestnikami. Za Joanną Tokarską-Bakir wskazać można przypadek Szwajcara, Benjamina Wlkomirskiego, który w 1995 r. opublikował książkę Bruchstücke, w której opisywał rzekomo swoje doświadczenia z dzieciństwa, gdy był więźniem obozu koncentracyjnego. Kilka lat po wydaniu tej „autobiograficznej” książki okazało się, że wspomnienia autora zostały wymyślone[3].

Obok tak rozumianej postpamięci, gdy ktoś przyswaja sobie cudzy uraz, można wskazać także inne jej przejawy, np. rozmaite zafałszowania prowadzące do osobliwych, mitotwórczych ujęć przeszłości, jak w filmach Lista Schindlera (1993) Stevena Spielberga, Życie jest piękne (1997) Roberto Benigniego czy Bękarty wojny (2009) Quentina Tarantino.

[1] Artykuł ten jest uzupełnioną i w niektórych wątkach znacznie rozbudowaną wersją tekstu: Postpamięć jako marzenie senne - Achtung Zelig! Druga wojna Krzysztofa Gawronkiewicza i Krystiana Rosenberga, w: KOntekstowy MIKS. Przez opowieści graficzne do analiz kultury wspótczesnej, red. G. Gajewska,

R. Wójcik, Poznań 2011.

[2] M. Firsch, Family Frames: Photography, Narrative and Postmemory, Cambridge 1997, s. 22.
Images vol. IX/no. 17-18

Poznań 2011

ISSN 1731-45OX

\section{Wprowadzenie do problematyki postpamięci}


Termin postpamięć zaczyna więc funkcjonować w kontekstach odnoszących nie się tylko do grona bezpośrednich uczestników traumatycznych doświadczeń i ich najbliższej rodziny. Jest to pamięć wtórna, przybierająca często charakter mitotwórczego żywiołu ogarniającego współczesną przestrzeń kulturową, w której głos i świadectwo ofiar[4] zastępuje się monumentalizmem i fetyszyzowaniem przeszłości. Przywoływana etnografka zjawisko to wpisała w przestrzeń „kultury posttraumatycznej”, która rozszerzała się od końca lat osiemdziesiątych XX wieku, jako reakcja na wcześniejszą wzniosłą „kulturę milczenia" (Holocaust jako niewypowiedziane, jako pustka, niemożność tworzenia poezji po Auschwitz). Kultura posttraumatyczna jak pisze Tokarska-Bakir - „, skupia się wokół centralnego urazu, zadawnionego i wypartego, który niespodziewanie powraca i poddaje rewizji całą bieżącą rzeczywistość" [5]. Historyk Dominik La Capra wyjaśnia zjawisko postpamięci kurczącą się świadomością historyczną i zarzuca rozmaitym formom postpamięci zafałszowania przeszłości i nadużycia[6], natomiast Tokarska-Bakir tłumaczy rozszerzające się zjawisko kultury posttraumatycznej i postpamięci tym, że tradycyjna historiografia nie zadbała o krytyczną, dokładną i dostępną pamięć, nie sprawdziła się także w roli żałobnika. To, czego TokarskaBakir nie znajduje w akademickiej historiografii, dostrzega w książkach Jana Tomasza Grossa i Daniela Jonaha Goldhagena[7], natomiast Ewa Domańska w architektonicznej realizacji muzeum w Berlinie autorstwa Daniela Libeskinda 2000 lat niemiecko-żydowskiej historii, mającej upamiętnić również Holocaust[8].

O ile utwory literackie, graficzne, architektoniczne, rzeźbiarskie należące do tzw. kultury wysokoartystycznej były już wielokrotnie analizowane $z$ perspektywy zjawiska postpamięci oraz kultury posttraumatycznej, o tyle obszar kultury popularnej pozostaje właściwie wyłączony $z$ tych analiz (wyjątek stanowią filmy, być może ze względu na swą narracyjno-wizualizacyjną nośność, a co za tym idzie stosunkowo duży oddźwięk społeczny). Tymczasem to właśnie kultura popularna w dużym stopniu wpływa na kształtowanie postaw i poglądów współcześnie żyjących ludzi. Wszechobecność popkultury, presja jaką wywiera w dużej mierze wpływa na przewartościowania całej kultury, nie tylko tej wiązanej ze sferą rozrywki. Kultura posttraumatyczna w dużej mierze kształtuje się $w$ i poprzez kulturę popularną, o czym świadczy poczytność opowieści graficznej Achtung Zelig! Druga wojna Krzysztofa Gawronkiewicza (rysunki) i Krystiana

[4] Należy podkreślić, że istotną kwestią owego przemieszczenia jest to, że pokolenie, które przeżyło wojnę, mogące dać świadectwo zbrodniom Holocaustu, ze względu na upływający czas, bezpowrotnie „odchodzi” z grona żywych.

[5] J. Tokarska-Bakir, op.cit., s. 98.

[6] D. La Capra, Writing History, Writing Trauma, Baltimore and London 2001.
[7] J. Tokarska-Bakir, op.cit., s. 101-102. Chodzi przede wszystkim o prace: J. T. Gross, Sasiedzi: historia zagłady żydowskiego miasteczka, Sejny 2000; Daniel J. Goldhagen, Gorliwi kaci Hitlera: zwyczajni Niemcy i Holocaust, przeł. W. Horabik, Warszawa 1999.

[8] E. Domańska, Historie niekonwencjonalne. Refleksja o przeszłości w nowej humanistyce, Poznań 2006, s. 195-220. 
Rosenberga (scenariusz) wykazująca wiele cech określanych mianem postpamięci.

Opowieść graficzna pozostaje na antypodach zainteresowań literaturoznawców, w dużej mierze dlatego, że dla opowiedzenia historii wykorzystywane są $\mathrm{w}$ niej elementy wizualne komponowane w sposób właściwy dla sztuk plastycznych. Zauważyć jednak trzeba, że opowieść graficzna zawdzięcza swą fabularność wzorom literackim. Chociaż narrację tworzą tutaj sekwencje obrazów (kadrów) to jednak współistnieją z tekstem i zachowują swą literacką proweniencję. $\mathrm{Na}$ potrzeby niniejszego szkicu, narrację postrzegam jako zbiór wszystkich elementów tekstu składających się na fabułę, a także zasady, dzięki którym są one łączone. Synonimem tego pojęcia jest dla mnie opowiadanie (ale nie w rozumieniu gatunkowym). Odchodzę od językowej - wręcz gramatycznej - analizy narracji przeprowadzanej przez narratologów. Ponieważ celem tego artykułu jest wykazanie, że opowieść graficzna Gawronkiewicza i Rosenberga należy do formacji postpamięci, skupiam się przede wszystkim na warstwie narracyjnej i na tym, jak w tej specyficznej, opartej na jedności ikono-lingwistycznej[9] opowieści ujawnia się powrót zadawnionego i wypartego urazu Holocaustu.

Utwór Achtung Zelig! Druga wojna wydało w 2004 roku wydawnictwo Zin Zin Press[10]. To, co wyróżnia ten utwór, to specyfika jego tematu i desygnatu. Osią pracy jest temat antysemityzmu, faszyzmu, ludobójstwa, a więc historia, która i tak jest już niezwykle często zapośredniczana przez kulturowe (literackie, plastyczne, filmowe) reprezentacje. Mamy tu do czynienia $z$ opowieścią graficzną, która

\section{Powrót tego, co wyparte}

[9] Określenie „jedność ikono-lingwistyczna” w odniesieniu do specyfiki narracji komiksów wprowadził w 1976 roku Bernard Toussaint [Zob. K. T. Toeplitz, Sztuka komiksu. Próba definicji nowego gatunku artystycznego, Warszawa 1985, s. 21]. Chociaż powstają komiksy, w których narracja budowana jest wyłącznie za pomocą sekwencji obrazów, to analizowany tu komiks Achtung Zelig! Druga wojna pod względem strukturalno-formalnym wykazuje cechy klasycznego komiksu, co pozwala na stwierdzenie, że jego narracja opiera się na jedności ikono-lingwistycznej. Na marginesie warto zwrócić uwagę, że w komiksie Gawronkiewicza i Rosenberga jedność ta przybiera dodatkowo jeszcze inną formę niż w klasycznym komiksie (rysunki i tekst), mianowicie graficzny sposób zapisu tekstu implikuje określone znaczenie. Przykładowo, w kilku kadrach do zapisu zawołań (halt!) i śmiechu (ha! ha! ha!) niemieckich żołnierzy użyto fontu Gothic, który był stosowany w tytulaturze, a czasami w dłuższych tekstach (np. obwieszczeniach) wydawanych przez Rzeszę Niemiecką pod rządami NSDAP w latach 1933-1945. Użycie tego fontu w komiksie o pojmaniu Żydów przez niemiecki patrol nakłada na tekst „siatkę” określonych skojarzeń i odwołań do konkretnego okresu historycznego oraz problematyki prześladowań ludzi pochodzenia żydowskiego. Specyfika jedności ikono-lingwistycznej w utworze Achtung Zelig! Druga wojna polega także na zastąpieniu znaku zapytania (?) rysunkiem przedstawiającym przyrząd przypominający suwmiarkę lub kraniometr (używany do pomiarów kątów i łuków czaszki w celu określenia różnic rasowo-antropologicznych). Zamiana znaku zapytania na kraniometr nastąpiła w kadrze przedstawiającym nieudaną ucieczkę Zeliga i jego ojca - bohater zastanawia się po czym przywódca patrolu rozpoznał, że są Żydami. Użycie w rym kadrze suwmiarki/kraniometru jako pytania o to „kim są ci podróżnicy?” kieruje uwagę ku rasowo-antropologicznym kryteriom identyfikacji wyznaczonym przez nazistów.

[10] K. Gawronkiewicz, K. Rosenberg, Achtung Zelig! Druga wojna, Warszawa-Poznań 2004. 
przekazuje historię jako coś już przedstawionego, zapośredniczonego przez media kultury. Świadczą o tym literackie, plastyczne, a także reklamowe inspiracje Gawronkiewicza i Rosenberga, które wpłynęły na określoną treść i szatę graficzną utworu Achtung Zelig! Druga wojna. Gawronkiewicz w wywiadzie udzielonym jesienią 2003 roku mówił, że jedną z inspiracji do stworzenia komiksu była lektura wspomnień kobiety, która wraz z córką próbowała przemknąć obok stacjonujących Niemców. Wspomnienia z okresu wojennego skojarzył z jakąś współczesną reklamą ukazującą ojca i syna, którzy idąc trzymają się za ręce. Zdjęcie $\mathrm{z}$ tej reklamy zostało przerysowane przez Rosenberga, w wyniku czego ojciec przybrał kształt monstrualnej postaci, a syn zaczął przypominać płaza. Ponieważ kobieta, której wspomnienia czytał Gawronkiewicz była Żydówką, grafik uznał, że bohaterowie jego nowego komiksu również będą Żydami[11]. Już $\mathrm{w}$ tej relacji ujawniają się cechy postpamięci: inspiracja cudzymi wspomnieniami oraz pamięć zapożyczona przez media. Za symptomatyczne można uznać także powołanie się Gawronkiewicza na mitotwórcze wyobrażenia o II wojnie światowej ukształtowane przez popularne seriale telewizyjne, takie jak Czterej pancerni i pies oraz $\mathrm{Ka}$ pitan Kloss[12]. W ten sposób wkraczamy w wizję wojny nieprawdziwej, chociaż z wyraźnym zaznaczeniem, że w komiksie Achtung Zelig! Druga wojna nie mamy do czynienia ze świadomym fałszowaniem przeszłości, lecz raczej z jej uobecnieniem w nowej: zapośredniczonej, zniekształconej, przerysowanej formie postpamięci.

Akcja komiksu toczy się na początku II wojny światowej, w okupowanej przez Niemców Polsce, a jej bohaterami są dwaj Żydzi (syn i ojciec), którzy zostali zatrzymani przez patrol niemieckich żołnierzy. Praca ta nie ma charakteru wspomnieniowego (jak na przykład przywołany już komiks Maus Arta Spiegelmana), została bowiem stworzona przez ludzi, którzy urodzili się wiele lat po wojnie, a protagoniści komiksu to postacie fikcyjne. Autorzy opowiadają jednak historię tak, jakby była ona wspomnieniem jednego z bohaterów Żyda, który przeżył II wojnę światową, co samo w sobie ma już cechy pamięci zapożyczonej. Na pierwszej karcie komiksu tytułowy Zelig wypowiada słowa: „Jestem już stary i przez te wszystkie lata nawet przez chwilę nie żałowałem wyboru, który się na mnie dokonał, pomimo, że historia mojego narodu to nieustanna wędrówka, cierpienie i łzy...”[13]. Czytelnik/widz odnosi wrażenie, że oto za chwilę rozpocznie się opowieść świadka i uczestnika tragicznych wydarzeń sprzed kilkudziesięciu lat. Faktycznie mamy tu do czynienia z czymś innym - osobliwym, mitotwórczym żywiołem na temat traumy Holocaustu, karmiącym się - co charakterystyczne dla postpamięci - wpa-

[11] M. Herman, Wizja wojny nieprawdziwej o powstaniu komiksu „Achtung Zelig!” i przyszłości rozmawiamy z Krzysztofem Gawronkiewiczem, http://www.esensja.pl/komiks/wywiady/tekst.html?id $=664 \&$ strona $=1($ data odczytu: 23.01 .2011$)$.

[12] Ibidem.

[13] K. Gawronkiewicz, K. Rosenberg, op.cit., s. 5. 
trywaniem w niezabliźnioną ranę. Znamienne pod tym względem jest cytowane wyżej sformułowanie "historia mojego narodu to nieustanna wędrówka, cierpienie i łzy”. W ten sposób zarysowuje się swoisty kontekst, który można określić jako wspólny dla Europejczyków, chociaż w różnym stopniu uświadomiony i rozmaicie akcentowany, kompleks winy za zbrodnie Holocaustu. W analizowanym komiksie ujawnia się to w wypowiedzi starego Zeliga: „Człowiek nie wybiera narodu to naród wybiera człowieka. Nie każdy rodzi się - dajmy na to Szwajcarem. No cóż, siła wyższa" [14]. Przywołanie przez protagonistę anonimowego Szwajcara można interpretować jako aluzję do formalnej neutralności Szwajcarii podczas II wojny światowej, ale także szerzej - jako aluzję do obojętności wielu Europejczyków wobec losu Żydów podczas wojny. Ta niezabliźniona rana, poczucie dyskomfortu psychicznego wobec ofiar przybrało w kulturze posttraumatycznej rozmaite formy, które spróbuję dalej przeanalizować posługując się kategorią kiczu.

Herman Broch w eseju Kilka uwag o kiczu zauważał, że istotą kiczu jest mylenie kategorii etycznej z estetyczną, kicz działa bowiem pięknie, a nie dobrze, przekształca życie ludzkie w dzieło neurotyczne, narzucając rzeczywistości nierealną konwencję[15]. W pewnej mierze tropem tym podąża Lisa Saltzman[16], która w artykule Awangarda $i$ kicz raz jeszcze. O etyce reprezentacji zauważa, że kwestia przedstawiania Holocaustu w kulturze współczesnej jest tyleż problem estetycznym, co etycznym. W jej ujęciu kultura popularna otwierająca się na estetykę kiczu porzuciła wszelkie pretensje do wzniosłości, a skierowała się ku wystudiowanemu, wyrafinowanemu i ironicznemu dystansowi. W ujęciu Saltzman „Kicz w połączeniu z przedstawieniem historii, historii faszyzmu, Holocaustu, ludobójstwa czyni tę historię zbyt zrozumiałą, przyswajalną, łatwą do konsumpcji” [17]. Z tej perspektywy komiks Achtung Zelig! Druga wojna jawi się jako realizacja kiczowata, chociaż bowiem utwór pod względem estetycznym został dopracowany w każdym szczególe (łącznie z graficzną erratą), to jednak poprzez swą neurotyczność, kiczowatość wydaje się niebezpieczny, czy - według kryteriów określonych przez Brocha - zły, nieprawdziwy. Popkulturowe reprezentacje Holocaustu demaskują kicz wykorzystywany w estetyce faszystowskiej, ale jednocześnie podejmują grę z tym kiczem i traktują go jako strategię artystyczną, co wywołuje w odbiorcach poczucie dotkliwego dyskomfortu. Propozycja złożona przez autorów komiksu Achtung Zelig! Druga wojna również opiera się na tej dialektyce, o czym świadczą liczne elementy „zbawczego kiczu”,

[14] Ibidem, s. 5.

[15] H. Broch, Kilka uwag o kiczu i inne eseje, przeł.

D. Borkowska, Warszawa 1998, s. 114-115.

[16] Badaczka co prawda nie powołuje się na esej Brocha, lecz esej Clementa Greenberga Avant-Garde and Kitsch z 1939 roku (Art and Culture: Critical
Kicz jako kategoria (nie)etyczna
Essays, Boston, 1961, s. 3-21), lecz jej analizy można $\mathrm{z}$ powodzeniem umieścić także $\mathrm{w}$ kontekście rozważań Brocha.

[17] L. Saltzman, Awangarda i kicz raz jeszcze. O etyce reprezentacji, przeł. K. Bojarska, „Literatura na Świecie" 2004, nr 1-2, s. 204. 
Wizerunki Żydów jako istot o nieokreślonej taksonomii

Ilustracja 1.

Bohaterowie komiksu przedstawieni jako istoty o nieokreślonej taksonomii. K. Gawronkiewicz, K. Rosenberg, Achtung Zelig! Druga wojna..., s. 8. które postaram się ujawnić. Przez zbawczy kicz rozumiem takie reprezentacje, które transformują traumatyczne doświadczenia w fikcyjne melodramaty lub też nadają historycznym katastrofom wymiar katarktyczny, a co ważniejsze przebolenie zastępują przyjemnością ciągłego wpatrywania się w niezabliźnioną ranę. Analiza kilku kadrów i scen z komiksu Gawronkiewicza i Rosenberga wykaże, że tak rozumiany zbawczy kicz jak najbardziej przynależy do formacji postpamięci.

Głównych bohaterów schwytanych przez niemieckich żołnierzy przedstawiono jako postaci o nieokreślonej taksonomii: nie wyglądają jak ludzie, ani jak żaden znany gatunek zwierząt. Co prawda głowa jednego z protagonistów kojarzy się z wyglądem żaby, lecz jego tułów jest antropomorficzny, co nie pozwala na jednoznaczną identyfikację, $\mathrm{z}$ kolei drugi bohater bardziej przypomina pozaziemskie monstrum z filmowego cyklu fantastycznonaukowego Obcy zapoczątkowanego w 1979 roku przez Ridleya Scotta niż jakąkolwiek ziemską istotę. Ten artystyczny zabieg można interpretować jako trawestację ideologii faszystowskiej, w której nację żydowską określano jako podludzi, jednocześnie nie definiując tego pojęcia. Negatywnie nacechowanego pojęcia „podludzi” nie można przecież wyprowadzić z pojęcia „ludzie”. Z zestawienia przeciwstawnej pary pojęć asymetrycznych: „człowiek” i „podczłowiek” nie wynika żadna charakterystyka "podczłowieka”, lecz jest to puste hasło używane w celach ideologicznych dla utrwalenia pozycji grupy nazistów sprawującej władzę na przełomie lat trzydziestych i czterdziestych XX wieku[18]. Owa pustka semantyczna została ujęta przez autorów komiksu w formie graficznej, jako wizerunki postaci, których nie można zidentyfikować pod względem gatunkowym (il.1). Wygląd zewnętrzny Zeliga i jego ojca określić można jako potworny, przeraźliwy, monstrualny, właśnie dlatego, że nie mieści się on w ramach nazistowskiego hasła czystości rasowej.

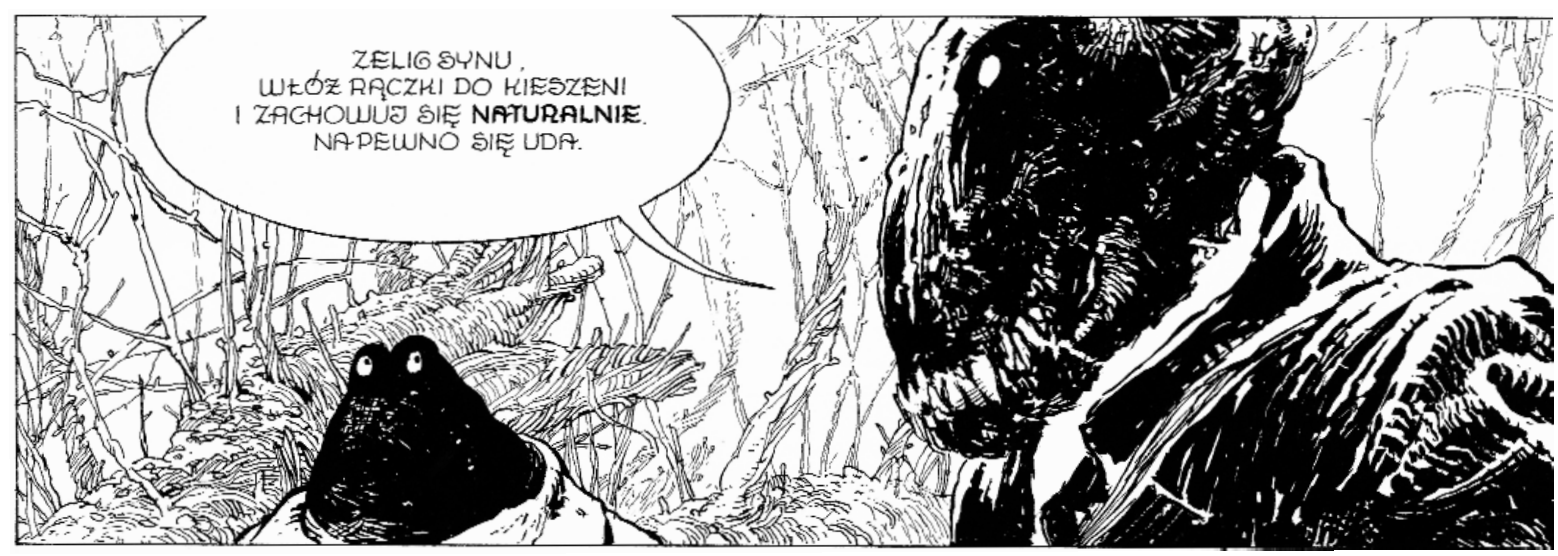

[18] Na ten temat zob. R. Koselleck, O historycznopolitycznej semantyce przeciwstawnych pojecć asymetrycznych, w: idem, Semantyka historyczna, wybór i opracowanie H. Orłowski, przeł. W. Kunicki, Poznań 2001, s. 283-283. 


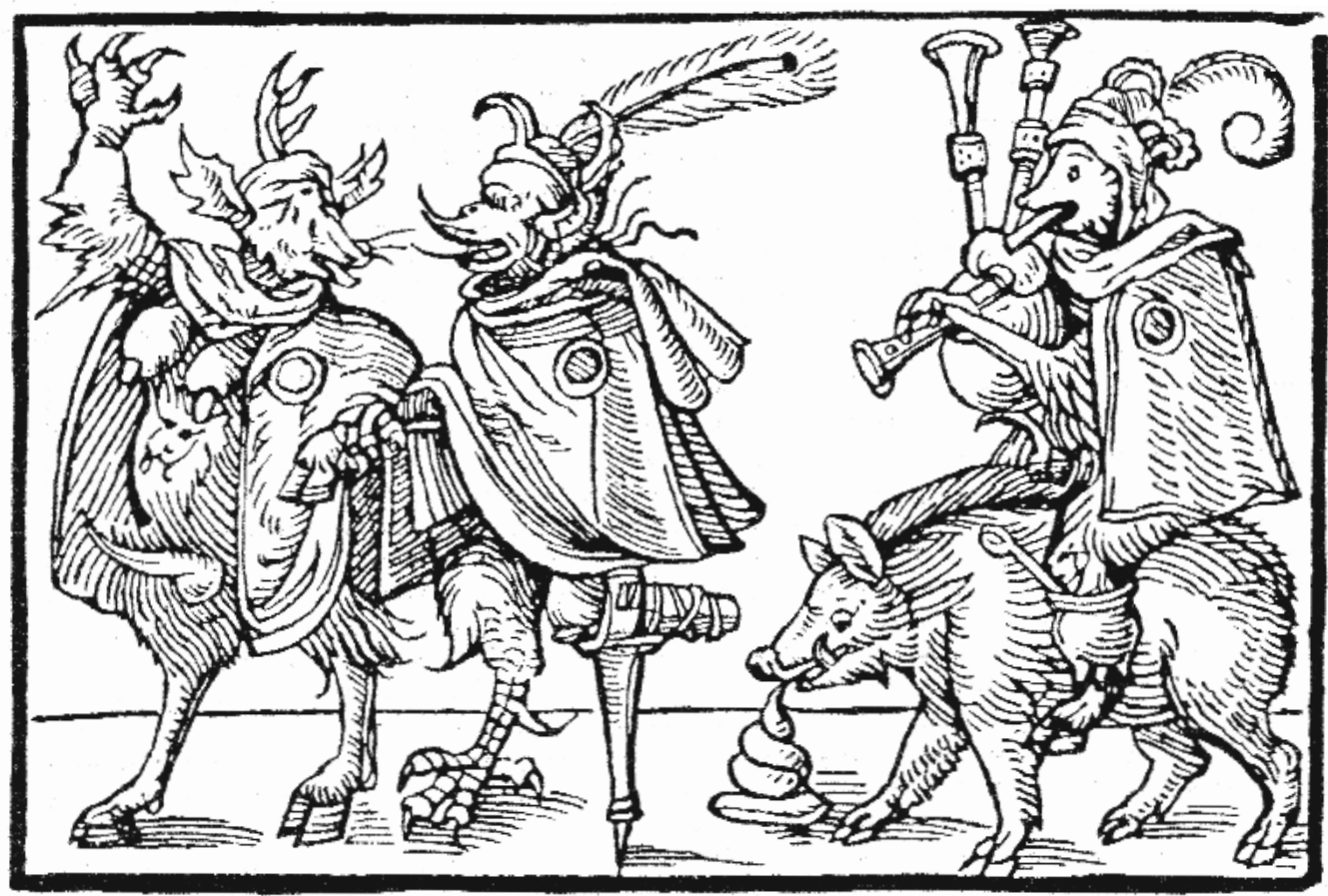

\section{ANNO. M, D. LXXI:}

Za Theodorem Adorno można pójść jeszcze dalej. W Dialektyce oświecenia (we fragmencie Minima moralia) filozof zauważa, że społeczny schemat percepcji u antysemitów jest prawdopodobnie tak ukształtowany, że w ogóle nie postrzegają oni Żydów jako ludzi[19]. $\mathrm{Z}$ tej perspektywy wygląd bohaterów komiksu jawi się jako trawestacja owej „patologicznej projekcji”. Potworność ich wyglądu odsyła także do mocno utwierdzonego w kulturze europejskiej sposobu przedstawiania Obcych w ogóle (rasowo, religijnie, obyczajowo)[20], co potęguje określone wyobrażenie o Żydach jako Obcych zagrażających swojskości (Żydzi jako grupa o odmiennej religii i obyczajach postrzegani byli jako Inni, lecz w sytuacji zagrożenia - rzeczywiste-
Ilustracja 2.

Rycina z 1571 roku ukazująca taniec Żydów, na której nację żydowską ukazano jako monstrulną, niemożliwą do zidentyfikowania pod względem gatunkowym. Ilustracja pochodzi z: E. Fuchs, Die Juden in der Karikatur: ein Beitrage zur Kulturgeschichte. München 1921.
[19] M. Horkeimer, T. Adorno, Dialektyka oświecenia, przeł. M. Łukasiewicz, Warszawa 1994. [20] Myślenie o przedstawicielu innej kultury jako zwierzęciu, czy ludzko-zwierzęcej hybrydzie jest bardzo zakorzenione w kulturze europejskiej sposobem wyznaczania granicy między własnym a obcym.

Pliniusz Starszy w Historii naturalnej z 77 r. n.e. opisując fikcyjne ludy zamieszkujące Afrykę, pozbawiał je ludzkich cech wyglądu i zachowania. Według niego „Blemmyom podobno brak głów, a usta i oczy mają na piersiach. Satyrowie poza postacią nie wykazują nic z obyczaju ludzkiego", a Ajgipanowie mają koźle nogi, natomiast Himantopodowie, zwani też jako
Rzemieniostopi „odznaczają się właściwością poruszania się przy pomocy pełzania" [Pliniusz, Historia naturalna (wybór), przeł. i komentarz I. i T. Zawadzcy, wstęp I. i T. Zawadzcy oraz L. Hajdukiewicz, Wrocław-Kraków 1961, s. 48]. Marco Polo opisując ludy z odległych krain, powoływał się na „znane wszystkim fakty” o Pigmejach: „Wiecie zaiste, że wszyscy mieszkańcy tej wyspy mają głowy psie oraz oczy i zęby jak psy, gdyż ręczę wam, że z głowy podobni są zupełnie do wielkiego psa doga [...] Wszystkich ludzi, jakich pojmać zdołają, a którzy nie należą do ich narodu, zjadają" [M. Polo, Opisanie świata, przeł. A. L. Czerny, wstęp M. Lewicki, War- 


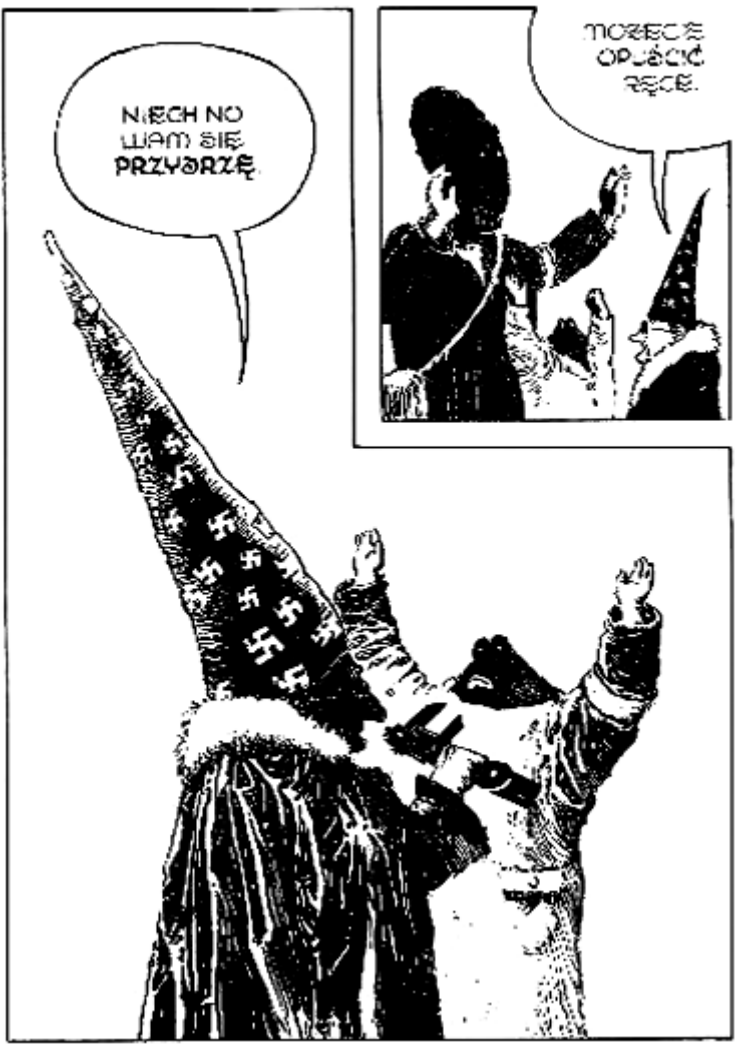

go lub projektowanego - odczuwanego przez sąsiadów, stawali się Obcymi, których na podstawie arbitralnie przyjętych założeń identyfikowano i wykluczano il. 2). W komiksie Achtung Zelig! Druga wojna wzmocnienie tego przekazu następuje w kadrze, w którym Zelig zastanawia się, po czym karzeł-mag poznał, że jest on Żydem, co graficznie oddaje rysunek narzędzia mierniczego - kraniometru, zamiast znaku zapytania (il. 3). Narzędzie to można traktować jako symbol rasowoantropologicznych badań nazistów mających na celu określenie wyraźnych różnic między rasą aryjską a innymi rasami (il. 4).

W takim przedstawieniu protagonistów skrywa się jednak niebezpieczeństwo, ponieważ monstrualne sylwetki Żydów utwierdzają - poprzez powtórzenie, a jednocześnie przerysowanie - stereotypowe wyobrażenia o Żydach jako nieludziach czy podludziach. Podstawowe pytanie, które powraca $\mathrm{w}$ kontekście tych przedstawień brzmi „czy to jest czło-

Ilustracja 3 i 4.

Suwmiarka widniejąca na dwóch kadrach komiksu symbolizująca rasowoantropologiczne badania nazistów w latach trzydziestych i czterdziestych XX wieku. K. Gawronkiewicz, K. Rosenberg, Achtung Zelig! Druga wojna..., s. 9, 15. wiek?", a samo sformułowanie takiego pytania wobec historycznej świadomości mordów dokonywanych na Żydach uzasadnianej ich nieludzkim (podludzkim) statusem ontologicznym jest niebezpieczne. Chociaż możemy przypuszczać, że celem Gawronkiewicza i Rosenberga jest demaskacja faszystowskiej retoryki i estetyki podważającej nie-ludzki status Żydów, to jednak w odbiorze mamy do czynienia raczej z okaleczaniem tej grupy, ponieważ elementy nazistowskiej ideologii wchodzą do repertuaru popkulturowych reprezentacji traumy wojennej. Jest to jeden z powodów dla którego możemy mówić, że komiks ten należy do formacji postpamięci. szawa, 1975, s. 291-292]. Nie tylko mieszkańcy Europy zachodniej postrzegali przedstawicieli innych kręgów kulturowych jako zwierzęta. W XIX w. Turcy, których drażniło zachowanie i styl ubierania się ludzi z Zachodu nazywali ich małpami oraz kozłami lub małpami bez ogonów, jeszcze w XX w. muzułmanie z Imperium Osmańskiego pogardliwie określali chrześcijan psami, wieprzami, a także diabłami [Zob. B. Jezernik, Dzika Europa: Bałkany w oczach zachodnich podróżników, przeł. P. Oczko, Kraków 2004, s. 32]. Tego rodzaju opisy Obcych można dostrzec także w naszej rodzimej kulturze. Gall Anonim przed- stawiał Prusów jako istoty, które należy pozostawić „z nierozumnymi zwierzętami” [G. Anonim, Kronika polska, przeł. R. Grodecki, oprac., wstęp M. Plezia, Wrocław-Kraków 1982, s. 106]. Później dla Polaków dzikimi plemionami byli Tatarzy, Turcy, ale także najbliżsi sąsiedzi, którzy ze względu na odmienność religii i obyczajów (jak Żydzi) nie asymilowali się z katolicką społecznością. Nie trudno zauważyć, że mamy do czynienia zarówno z ciekawością i fascynacją, jak i z wartościowaniem: obcy wydają się nie tylko intrygujący, lecz także dzicy, przerażający, nie-ludzcy. 


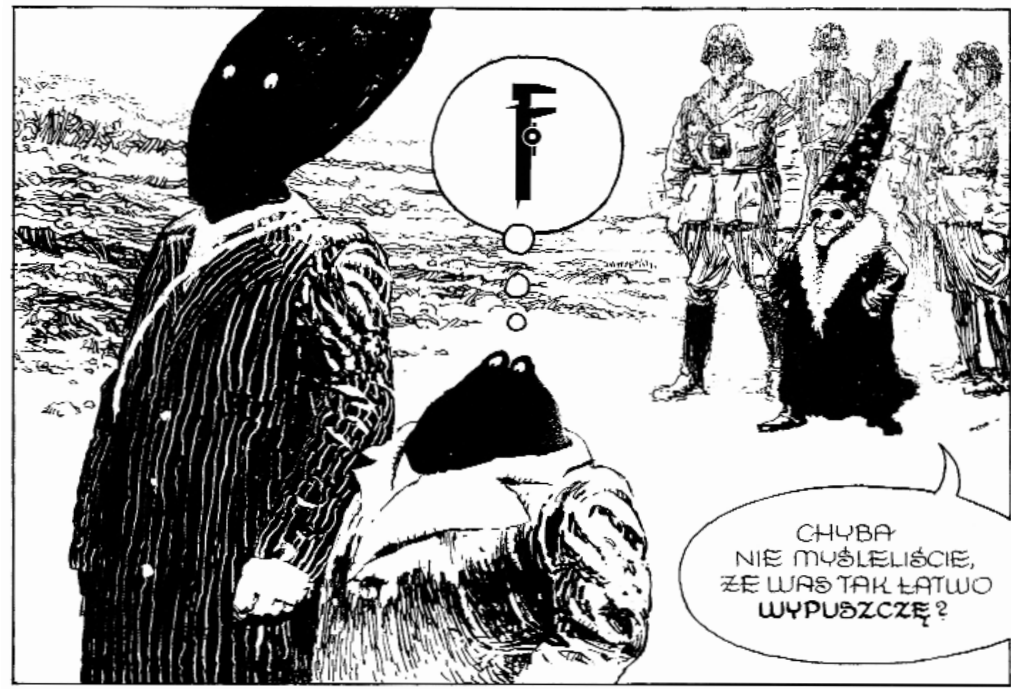

Kolejnym powodem dla którego komiks Achtung Zelig! Druga wojna należy uznać za przynależny formacji postpamieci jest sposób zestawiania znaków. Czytelnik/widz wkładając wysiłek w odszyfrowanie nakładających się, to znów nieprzystających do siebie kodów skupia się przede wszystkim na grze intertekstualnej i kontekstualnej, którą proponują autorzy komiksu. W tej grze problem antysemityzmu, prześladowań Żydów przed II wojną światową, podczas wojny, Holocaust schodzi na drugi plan, czy raczej zostaje zneutralizowany, dostarczając odbiorcy przede wszystkim przyjemności z oglądania i odczytywania nakładających się na siebie znaków.

Jedną z bardziej intrygujących postaci w komiksie Achtung Zelig! Druga wojna jest karzeł Emil dowodzący patrolem. Nie przedstawiono go $\mathrm{w}$ mundurze (jak pozostałych żołnierzy), lecz w długim płaszczu wykończonym futrem i w spiczastej czapce, na której widnieją swastyki (il. 5). Ukazanie dowódcy jako karła można interpretować jako satyryczną odpowiedź na propagandowe wizerunki aryjczyków $\mathrm{z}$ lat trzydziestych i czterdziestych XX wieku: atletycznie zbudowanych, o wyrazistych, ostro zaznaczonych rysach twarzy. Widniejące na kapeluszu nadruki swastyki zmuszają do usytuowania tej postaci w fikcyjnym (fantastycznym), a jednocześnie nie-fikcyjnym kontekście historycznym. Karzeł w przebraniu baśniowego maga jawi się jako pan życia i śmierci o wielkiej mocy, co ma odniesienie do wyjątkowych
Ilustracja 4

Karzeł polujący na koty

Ilustracja 5.

Jeden $\mathrm{z}$ bohaterów komiksu, karzeł dowodzący patrolem żołnierzy przedstawiony w długim płaszczu i wysokiej, spiczastej czapce. K. Gawronkiewicz, K. Rosenberg, Achtung Zelig! Druga wojna..., s. 15.

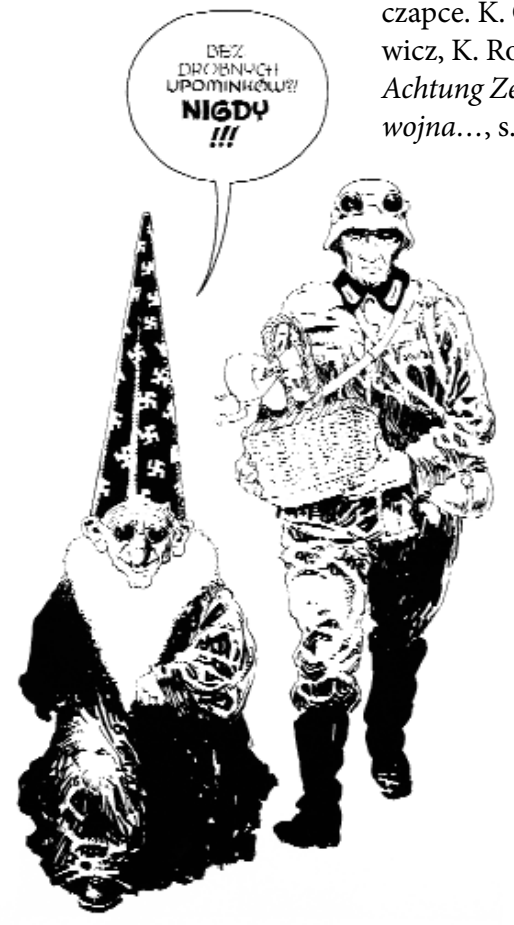


uprawnień członków SA oraz SS. W tym kontekście swastyki na kapeluszu karła jawią się jako namiastka umundurowania, podkreślenie przynależności do określonego ruchu i ideologii.

W interpretacji znaczenia tej postaci w komiksie o prześladowaniach Żydów można jednak podążyć innym tropem. W Europie zachodniej okresu średniowiecza spiczaste, żółte kapelusze były negatywnym sposobem wyróżniania Żydów (później była to gwiazda Dawida $\mathrm{w}$ tym samym kolorze)[21]. Z kolei swastyka kojarzona dziś przede wszystkim $\mathrm{z}$ ideologią ruchu faszystowskiego, występowała w wielu kulturach jako symbol pomyślności, także w kulturze judaistycznej - symbol ten odkryto na palestyńskich synagogach powstałych 2000 lat temu. W tym kontekście obraz spiczastej czapki z nadrukami swastyk umieszczonej na głowie dowódcy patrolu można interpretować jako wskazanie na odwieczne deprecjonowanie Żydów, które osiągnęło apogeum w faszystowskim planie „ostatecznego rozwiązania”.

Jednocześnie można przyjąć zupełnie inną interpretację - komiczny wygląd i przedziwny ubiór protagonisty ma na celu ośmieszenie eklektycznej symboliki/religii nazistowskiej i jej wyznawców, co znajduje uzasadnienie w tej części utworu, w której dowiadujemy się, że dowódca patrolu był niegdyś klownem cyrkowym. W ten sposób powaga (czy nawet wzniosłość rozumiana jako postawa etyczno-estetyczna awangardy) ustępuje miejsca postawie wystudiowanego, a zarazem ironicznego dystansu. Czytelnik/widz skupia się przede wszystkim na wielorakich możliwościach interpretacji poszczególnych scen, traktuje komiks jak labirynt-zagadkę, której rozwiązanie dostarcza wiele przyjemności, odsuwając w cień problem kształtowania ideologii nazistowskiej oraz jej symboliki.

Kolejnym powodem skłaniającym do wniosku, że Achtung Zelig! Druga wojna należy do formacji postpamięci jest taki sposób opowiadania historii dwóch Żydów jakby opowiadano o czymś innym. Zgodnie z klasyczną definicją, trauma powoduje rozszczepienie afektu (doznań) i reprezentacji (władz poznawczych). Człowiek w tym stanie czuje coś, czego nie może sobie przedstawić, a jednocześnie w owym odrętwieniu usiłuje przedstawić coś, czego nie może poczuć[22]. W konsekwencji przedstawienie staje się odrealnionym i sublimowanym (w sensie psychologicznym) śladem czegoś innego. W komiksie Gawronkiewicza i Rosenberga ujawnia się to w opowieści o wyłapywaniu kotów. Zwierzęta chwytane przez żołnierzy, zamykane są w naczepie samochodu i przewożone w nieznane miejsce. Polowanie na koty przywodzi na myśl łapanki Żydów organizowane przez nazistów i wywożenie ich do obozów koncentracyjnych oraz obozów zagłady. W komiksie Achtung Zelig! Druga wojna widnieje kadr ukazujący protagonistów stojących przed naczepą samochodu, w której zamknięto już 
wiele zwierząt i w której znajdą się także dwaj Żydzi, jakby autorzy nie wprost wskazywali zbieżność między losem kotów chwytanych przez tzw. hycli a losem Żydów pojmanych przez faszystów. Z perspektywy psychoanalitycznej opowieść o polowaniu na koty interpretować można jako mechanizm obronny, próbę reprezentacji tego, czego samemu się nie doświadczyło i czego nie sposób ogarnąć za pomocą władz poznawczych. Tu przechodzimy do najważniejszego zagadnienia, jakim jest przepracowywanie traumy Holocaustu w omawianym komiksie w sposób, przypominający zapis po przebudzeniu ze snu.

W recenzjach komiksu Gawronkiewicza i Rosennberga zwracano uwagę na surrealistyczną estetykę utworu, nie rozwijając jednak tego zagadnienia[23]. Należy więc uściślić, że porównanie obrazów z omawianego komiksu do metod wypracowanych w ramach surrealizmu ma sens przede wszystkim w odniesieniu do drogi onirycznej tego kierunku i tzw. metody paranoiczno-krytycznej w wydaniu Salvadora Dalego, polegającej na czymś w rodzaju kalkowania marzeń sennych[24]. W takiej paranoiczno-krytycznej perspektywie komiks Achtung Zelig! Druga wojna jawi się jako artystycznie przepracowana reprezentacja przeszłości. W komiksie zjawiska urojone, rozumiane (za surrealistami) jako marzenia na jawie, wizje z pół-snu, marzenia senne, a w niektórych przypadkach jako złudzenia halucynacyjne, ujawniają się jako fuzja tego, co wyobrażone $\mathrm{z}$ tym, co realne: protagoniści o fantastycznym wyglądzie współistnieją z bohaterami przedstawionymi realistycznie. Zestawienie realnie wyglądających postaci z postaciami fantastycznymi, lub ukazanie rzeczywiście istniejących ludzi, zwierząt, przedmiotów, lecz w zaskakujących sytuacjach, funkcjonuje tu jako artystyczny zapis snu tuż po przebudzeniu, jak czynili to niektórzy surrealiści. W tym sensie komiks Achtung Zelig! Druga wojna interpretować można w kategoriach eksperymentów przeprowadzanych na sobie samych (swej świadomości i nieświadomości), ale także na procesie twórczym, a nawet na percepcji jako takiej, która w ujęciu artystycznej awangardy z początku XX wieku traktowana była jako prawdziwa halucynacja (Hyppolyte Taine, a za nim André Breton powiadali, że „percepcja jest prawdziwą halucynacją”[25]).

Pod względem konstrukcyjnym mamy w komiksie do czynienia z czymś na wzór opowieści szkatułkowej - historia Zeliga i jego ojca jest śniona, a następnie przedstawiona przez Gawronkiewicza oraz Rosenberga, a w ich śnie bohaterowie śnią własne sny. Młodemu Zeligowi zamkniętemu wraz z kotami w naczepie samochodu śnią się drzwi z otworami na klucze. Widać także postać chłopca unoszącego się w powietrzu, który „przepływa” przez uchylone drzwi. Przekaz jest czytelny: Zelig marzy o tym, by wydostać się z miejsca, w którym go

[23] W. Orliński, Surrealistycznie o Holocauście, „Gazeta Wyborcza” 3-4 kwietnia 2004.
Holocaust jako koszmarny sen
[24] R. Passeron, Encyklopedia surrealizmu, przeł. Krystyna Janicka, Warszawa 1993, s. 63-78.

[25] Tamże, s. 66. 
uwięziono. Zgodnie z typologią Zygmunta Freuda mamy tu do czynienia $\mathrm{z}$ jasnym i rozsądnym marzeniem sennym, które miewają przede wszystkim dzieci. Według psychoanalityka marzenie takie „jest reakcją na przeżycia dzienne, które pozostawiły rozżalenie, tęsknotę, nie ziszczone życzenie. Marzenie senne przynosi bezpośrednie i niemaskowane spełnienie tego życzenia" [26]. Podążając tym tropem powiemy, że marzenie senne Zeliga o „przepłynięciu” przez drzwi stanowi reakcję na jego przeżycia: ucieczkę przed Niemcami, pojmanie przez patrol, zamknięcie w budzie samochodu.

Z kolei ojcu Zeliga śni się koszmar uwięzienia w tramwaju, w którym osaczają go dobrotliwie wyglądające i zachowujące się staruszki, dziadkowie, kobiety z dziećmi oczekujące, by ten ustąpił im miejsca. Za Freudem powiemy, że takie marzenie senne zastępuje w zniekształconej postaci treść, poprzez wywoływanie innych tworów zastępczych[27]. Interpretując ten sen można skojarzyć obrazy osaczania bohatera w tramwaju $\mathrm{z}$ sytuacją Żydów w nazistowskich Niemczech, a później w okupowanej Polsce, kiedy odmawiano im prawa do zasiedlania, sprawowania urzędów, konfiskowano majątki, niszczono obiekty sakralne. Sieć wykluczeń i obstrukcyjnych zachowań wobec tej nacji dotyczyła także uregulowań jazdy w tramwajach, w których Żydzi zobowiązani byli do ustępowania miejsc Niemcom. Można wnioskować, że utajone marzenia senne protagonisty komiksu Achtung Zelig! Druga wojna odnoszą się właśnie do tych wielorakich form deprecjonowania Żydów.

We śnie autorów komiksu (ale nie we śnie dwóch głównych bohaterów), misterny, zinstytucjonalizowany mechanizm owych prześladowań symbolizuje w komiksie Gawronkiewicza i Rosenberga wspominana już postać dowódcy patrolu w stroju maga. Zachowania tego zakompleksionego, ale także uprzejmego i dobrotliwego bohatera, który jednocześnie służalczo oddaje się powierzonej mu misji wyłapywania kotów oraz Żydów, przywodzi na myśl liczne dyskusje historyków, filozofów i publicystów na temat odpowiedzialności zwyczajnych ludzi, ojców, synów, którzy w szeregach militarnych i paramilitarnych stawali się mordercami. Bohater komiksu wyraża to następująco: „Ja tylko wykonuję rozkazy"[28], co przywodzi na myśl wypowiedzi wielu oskarżonych podczas procesów norymberskich w latach 1945-1949. W tym sensie komiks Gawronkiewicza i Rosenberga jest opowieścią o koszmarze sennym, który wydarzył się naprawdę.

\section{Podsumowanie}

Pomysł i proces powstawania komiksu odsłonięty przez Gawronkiewicza w przywoływanym na początku tego artykułu wywiadzie, a zwłaszcza dokonana tu analiza poszczególnych kadrów i scen utworu pozwala stwierdzić, że Achtung Zelig! Druga wojna wykazuje wiele cech określanych mianem postpamięci.

[26] S. Freud, Wstęp do psychoanalizy, przeł. S.

Kempnerówna i W. Zaniewicki, Warszawa, s. 141.
[27] Ibidem, s. 130.

[28] K. Gawronkiewicz, K. Rosenberg, op.cit., s. 20. 
Po pierwsze, w komiksie ujawniają się cechy pamięci wtórnej, zapożyczonej, autorzy utworu nie byli bezpośrednimi uczestnikami przedstawianych wydarzeń (chociażby ze względu na wiek), a ukazywana przez nich historia w dużym stopniu została zapośredniczona przez media kultury, takie jak: literatura wspomnieniowa, filmy wojenne, reklamy.

Po drugie, w utworze wykorzystano elementy faszystowskiej retoryki i jej wizualnych reprezentacji, na przykład wtedy, gdy głównych bohaterów przedstawia się jako nie-ludzi. Chociaż najprawdopodobniej takie przedstawienie ma na celu - poprzez szok - podważenie faszystowskiej koncepcji stawiającej Żydów poza gatunkiem ludzkim, to szafowanie takimi wizerunkami w kontekście wiedzy o mordach dokonywanych na tej nacji uzasadnianych jej nieludzkim statusem ontologicznym oznacza również okaleczanie. Nazistowskie formy reprezentacji nacji żydowskiej wchodząc do repertuaru ikonografii popkultury utwierdzają stereotypy, przyzwyczajają odbiorców do postrzegania Żydów jako podludzi, tak więc sam akt przedstawiania bierze udział w procesie kulturowego oswajania problemu antysemityzmu.

Po trzecie, w opowieści graficznej Gawronkiewicza i Rosenberga dawna postawa wzniosłego milczenia ustąpiła miejsca wystudiowaniu, wyrafinowaniu estetycznemu oraz ironicznemu dystansowi, który momentami zatraca się w jego pozorze - pastiszu, co należy do cech kultury posttraumatycznej. Utwór oparty jest na postmodernistycznym rozumieniu kiczu jako części „ciała sztuki” i jako integralnej części komunikatu artystycznego. W komiksie ujawnia się to jako cytowanie, przywoływanie, przerysowywanie, a nawet surrealistyczne zestawianie znaków. Utwór skłania do odnajdywania kontekstualnych i intertekstualnych odniesień dostarczając odbiorcy przede wszystkim przyjemności spowodowanej możliwością wielorakich interpretacji i odnajdywania w zestawionych znakach rozmaitych znaczeń, a to - jak wskazywałam na początku wywodu - należy do cech postpamięci.

Po czwarte, historia opowiedziana w komiksie sprawia wrażenie zapisu snu, co uwydatnione zostało w formie artystycznej tego utworu, w którym realizm miesza się z realizmem fantastycznym. Jeśli autorzy Achtung Zelig Druga wojna stawiają siebie w roli śniących, a następnie przedstawiających sen o prześladowaniach Żydów, to odbiorcy, by rozszyfrować zestawione znaki oraz ich znaczenie, postawieni zostają w roli psychoanalityków. W efekcie mamy więc do czynienia $\mathrm{z}$ sytuacją, w której nie dochodzi do analizy ani przedstawienia przeszłości, lecz tego, co wyparte, a następnie powracające w formie fantazmatycznych wyobrażeń o niej. Możemy żywić jedynie nadzieję, że ich ujawnienie sprowokuje czytelników/widzów do zadawania krytycznych pytań. Jeśli takie było wyzwanie postawione w komiksie Achtung Zelig! Druga wojna, to taka też jest jego zasługa. Innymi słowy, element prowokacji odgrywa w tym utworze o tyle ważną rolę, 
o ile nie pozwala czytelnikom/widzom na obojętny odbiór, za to skłania do konfrontowania swej wiedzy o przeszłości (lub zdobywania jej) z formami jej przedstawiania i upamiętniania. Ciągle otwarte i bez jednoznacznej odpowiedzi pozostaje jednak pytanie, czy komiks Achtung Zelig! Druga wojna spełnia to zadanie; na ile czytelnicy/widzowie dokonują owej konfrontacji, a na ile jego lektura dostarcza przyjemności wynikającej z odszyfrowywania znaków czy zabawy konwencjami. 